\title{
Automated Glycan Assembly of Oligogalactofuranosides Reveals the Influence of Protecting Groups on Oligosaccharide Stability
}

\author{
Narayana Murthy Sabbavarapu and Peter H. Seeberger*
}

Cite This: J. Org. Chem. 2021, 86, 7280-7287

Read Online

ABSTRACT: Galactofurans are an important structural constituent of arabinogalactan and lipopolysaccharides (LPS) ubiquitously present on the envelopes of all Mycobacteria. Key to the automated glycan assembly (AGA) of linear galactofuranosides as long as 20mers was the identification of thioglycoside building blocks with a fine balance of stereoelectronic and steric effects to ensure the stability of oligogalactofuranoside during the synthesis. A benzoylated galactofuranose thioglycoside building block proved most efficient for oligosaccharide construction.

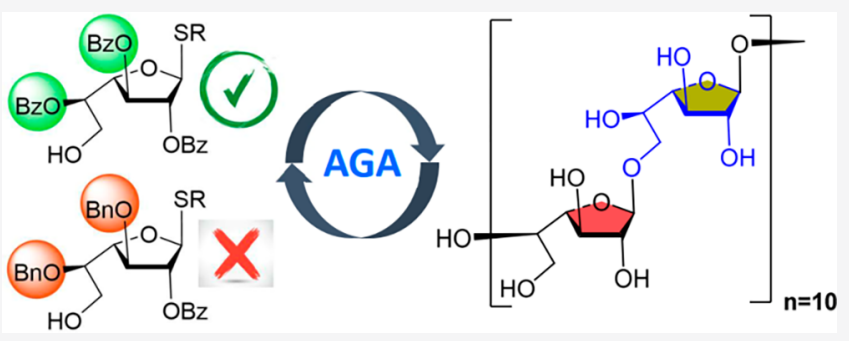

$\mathrm{T}$ uberculosis caused by Mycobacterium tuberculosis (M. $t b$.), kills more people than any other infectious disease. ${ }^{1} M$. $t b$. bacteria are surrounded by an intricate network of mycoyl chains that form a dense outer hydrophobic framework that is critical for survival and pathogenicity of the organism. ${ }^{2}$ The TB cell wall consists of two major structural components, arabinogalactan (AG) and lipoarabinomannan (LAM) that are both composed of D-galactose and D-arabinose furanoses. Arabinogalactan consists of a linear galactan backbone of approximately 30 alternating $\beta$ - $(1 \rightarrow 5)$ - and $\beta$ - $(1 \rightarrow 6)$-linked galactofuranose (Galf) residues. ${ }^{3}$ Furanose-containing oligosaccharides are important for microorganisms, but rarely found in humans and other primates. Therefore, the enzymes that are necessary for the construction of galactofuranosyl motifs in microorganisms are attractive targets for the development of new antituberculosis drugs. ${ }^{4}$ The low abundance of bifunctional galactofuranosyltransferase (GlfT2) and the structural heterogeneity of oligogalactofuranosides limits the access to probes for cell-wall biosynthesis and to determine substrate specificities. $^{5}$

Well-defined synthetic galactofuranosides that resemble the interior portion of AG are necessary to establish structureactivity relationships for these carbohydrates. ${ }^{6}$ Solution phase syntheses of galctofuranosyl oligomers ranging from 4 to 12 Galf residues have been reported. ${ }^{7}$ A stepwise synthesis of a galactan tetramer revealed structural constraints in the trisaccharide nucleophile that resulted in drastically reduced reactivity. Therefore, a "nonreducing to reducing end" strategy relying on monosaccharide nucleophiles was employed, to prepare a tetrasaccharide galactan. ${ }^{7 \mathrm{a}}$ The synthesis of longer galctofuranosyl oligomers relied on an iterative glycosylation approach. ${ }^{7 b, 8}$ A range of galactofuranosides were synthesized to probe substrate specificities in biological systems. ${ }^{9}$ Most oligosaccharide sequences were prepared via stepwise syntheses that require many discrete operations and multiple purifications.

Automated glycan assembly was developed to accelerate oligosaccharide synthesis. ${ }^{10}$ Over the past two decades, it has been improved to access more complex glycans. ${ }^{11}$ However, oligofuranosides were not prepared by AGA beyond short arabinofuranosides. ${ }^{12}$ To explore the utility of $\mathrm{AGA}^{11}$ to prepare oligogalactofuranosides, we wanted to test the limits of preparing linear galactans found on the surface of $M$. $t b$. Here, we disclose the automated synthesis of linear oligogalactofuranoside 20-mer 1 using building blocks with judiciously selected orthogonal protecting groups (Figure 1).

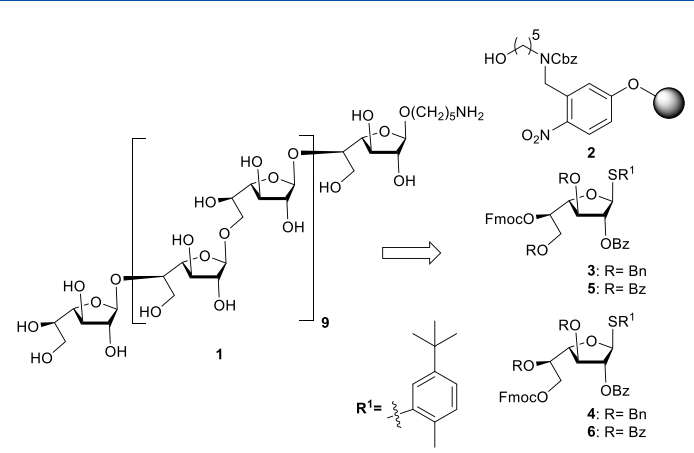

Figure 1. Retrosynthetic analysis of $\beta$-(1 $\rightarrow 5)$ - and $\beta$-(1 $\rightarrow 6)$-linked linear galactan 20-mer 1.

Received: March 2, 2021

Published: May 7, 2021 
The power of automated synthesis relies on the section of differentially protected monosaccharide building blocks that result in high yielding and completely selective glycosylations. Galactofuranose thioglycoside building blocks were designed to carry a temporary 9-fluorenylmethoxycarbonyl (Fmoc) protecting group at C-5 (3) or C-6 (4) respectively. A C-2 benzoate provides anchimeric assistance to ensure stereoselectivity for trans-glycosidic linkages. Regioselective benzoylation of thioglycoside $7^{13}$ was followed by 3-O-benzylation and subsequent aqueous acetic acid mediated hydrolysis of acetonide protection afforded diol 8 (Scheme 1). Trans-

Scheme 1. Synthesis of Building Blocks 3 and 4

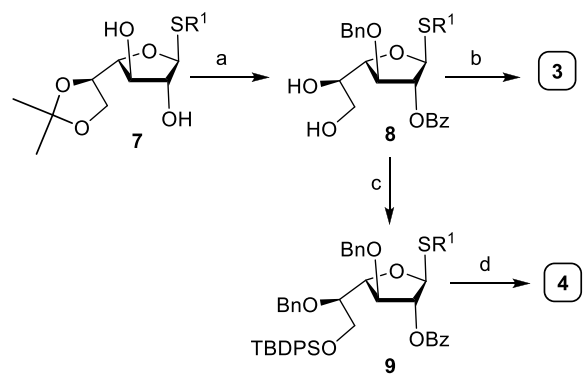

${ }^{a}$ Reagents and conditions: (a) (1) PhCOCl, Py., 46\%; (2) $\mathrm{Ag}_{2} \mathrm{O}$, $\mathrm{BnBr}, 78 \%$; (3) $\mathrm{AcOH} / \mathrm{H}_{2} \mathrm{O}, 80 \%$; (b) (1) $\mathrm{PhCH}(\mathrm{OMe})_{2}, \mathrm{CSA}, 72 \%$; (2) $\mathrm{Et}_{3} \mathrm{SiH}$, TFA, TFAA, 82\%; (3) FmocCl, Py., 87\%; (c) (1) TBDPSCl, Im., 82\%; (2) $\mathrm{Ag}_{2} \mathrm{O}, \mathrm{BnBr}, 75 \%$; (d) (1) TBAF, $\mathrm{AcOH}$, 65\%; (2) FmocCl, Py., 74\%.

acetalation of $\mathbf{8}$ with benzylaldehyde dimethyl acetal under acidic conditions preceded the regioselective opening of the benzylidene acetal using triethyl silane under acidic conditions before the C-5 hydroxyl was protected with Fmoc to furnish building block 3 in excellent yield. Building block 4 was prepared from 8 by selective protection as the corresponding TBDPS ether and 5-O-benzylation to access thiofuranoside 9. Selective cleavage of the silyl ether using acetic acid buffered TBAF, followed by installation of the C- 6 Fmoc provided building block 4 (Scheme 1).

With thioglycoside building blocks 3 and 4 in hand, photocleavable aminopentanol linker immobilized on polystyrene resin 2 was placed in the reaction vessel of the automated synthesizer to prepare galactan heptamer 10 (Scheme 2). A four-step AGA process consisting of acidic wash, glycosylation, capping to mask unreacted nucleophiles, and removal of the temporary protecting group to expose the nucleophile for the next glycosylation was executed. UV irradiation using a continuous flow device released the

Scheme 2. Synthesis of $\beta$ - $(1 \rightarrow 5)$ - and $\beta$ - $(1 \rightarrow 6)$-Linked Linear Galactan Heptamer 10 Using Building Blocks 3 and 4

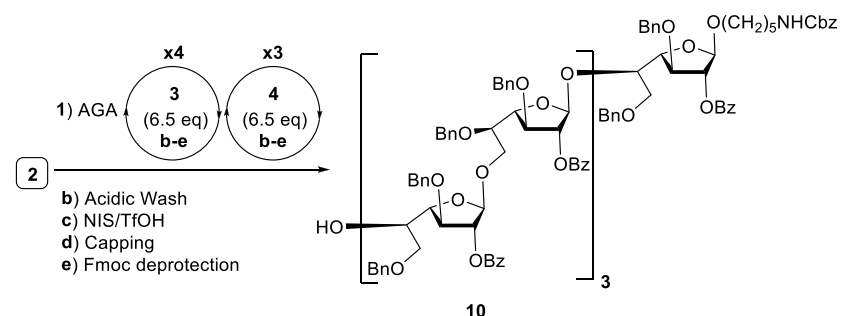

protected oligosaccharide products from the polymer support that were analyzed using analytical HPLC and MALDI. In addition to desired galactan heptamer 10, a host of deletion sequences were obtained. A careful analysis of the deletion sequences revealed that the temporary Fmoc protecting groups remained intact even after treatment with $20 \%$ piperidine in DMF. Changing the deprotection solution on the synthesizer to triethylamine (20\% in DMF), or DBU ( $5 \%$ in DMF) and a higher reaction temperature $\left(60{ }^{\circ} \mathrm{C}\right)$ failed to cleave Fmoc. The very hydrophobic Fmoc group may interact with hydrophobic regions of the sugar scaffold during oligosaccharide assembly to result in aggregation and poor reactivity.

To counteract aggregation and improve resin swelling, dichloromethane was used as solvent and the use of DBU (5\% in $\mathrm{CH}_{2} \mathrm{Cl}_{2}$ ) resulted in complete Fmoc cleavage. However, AGA of galactan heptamer $\mathbf{1 0}$ using the improved deprotection step revealed unwanted deletion sequences with exposed hydroxyl groups. Apparently, the arming benzyl ethers at C-3, C- 6 in building block 3 and C-3, C-5 positions in 4 have profound impact on the stability of the growing galactofuranoside due to intrinsic steric and stereoelectronic effects. ${ }^{14}$

On the basis of previous observations, we speculated that thiofuranosides 5 and $\mathbf{6}$ containing disarming benzoate esters may facilitate the assembly of linear oligogalactofuranoses. Building blocks 5 and 6 were prepared from thiofuranoside $7^{13}$ by benzoylation and isopropylidene cleavage to afford 11 . Regioselective benzoylation of $\mathbf{1 1}$ at low temperature and placement of Fmoc on the remaining secondary hydroxyl furnished 5. Selective silylation of the 6-hydroxyl in 11 with TBDPSCl and benzoylation gave 12. Desilylation of 12 by $\mathrm{HF} /$ pyridine followed by Fmoc protection yielded thioglycoside 6 (Scheme 3 ).

\section{Scheme 3. Synthesis of Building Blocks 5 and 6}

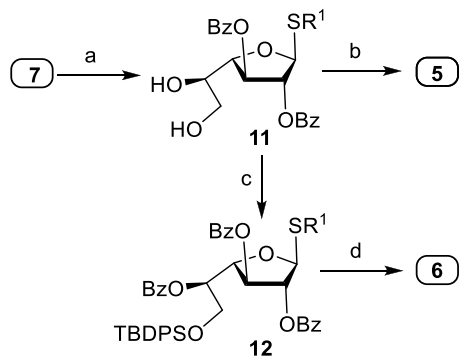

${ }^{a}$ Reagents and conditions: (a) (1) PhCOCl, Py., 86\%; (2) AcOH/ $\mathrm{H}_{2} \mathrm{O}$, 80\%; (b) (1) PhCOCl, Py., $\mathrm{CH}_{2} \mathrm{Cl}_{2},-60{ }^{\circ} \mathrm{C}, 82 \%$; (2) FmocCl, Py., 89\%; (c) (1) TBDPSCl, imidazole, 85\%; (2) PhCOCl, Py., 78\%; (d) (1) HF/Py., 72\%; (2) FmocCl, Py., $80 \%$.

AGA of galactan heptamer 13 using thiofuranosides 5 and 6 produced a single product according to the HPLC trace of the crude product (Scheme 4 and Figures S1 and S2). This encouraging result prompted us to prepare longer galactofuranose oligomers and to evaluate the influence of the protecting groups on the building blocks ( $\mathrm{Bn} v \mathrm{vz}$ ) on the stability of growing oligogalactofuranoside. Therefore, using the AGA process developed for shorter sequences, linear galactan 20mer 1 was assembled using building blocks 5 and 6 . HPLC and MALDI analysis of the crude mixture revealed that per- $O$ benzoylated furanoside glycosides 5 and $\mathbf{6}$ performed well. The desired product was purified by preparative HPLC and the structural integrity of protected galactofuranoside 20-mer 14 
Scheme 4. Synthesis of $\beta$ - $(1 \rightarrow 5)$ - and $\beta$ - $(1 \rightarrow 6)$-Linked Linear Galactan Heptamer 13 Using Building Blocks 5 and 6

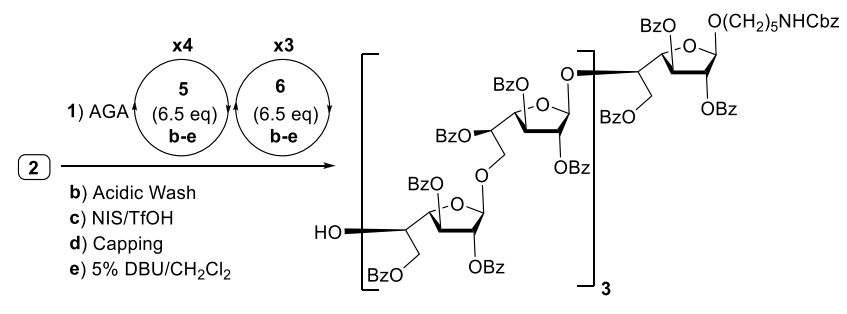

13

was confirmed by ${ }^{1} \mathrm{H},{ }^{13} \mathrm{C} \mathrm{NMR}$, as well as MALDI mass spectrometry (Scheme 5). Fully protected galactan $14(17 \mathrm{mg})$ was treated with sodium methoxide to cleave all benzoate ester groups, followed by $\mathrm{Pd}(\mathrm{OH})_{2} / \mathrm{C}$-catalyzed hydrogenolysis in the presence of hydrogen to cleave the $\mathrm{Cbz}$ group furnishing linear galactan 20-mer 1 ( $2 \mathrm{mg})$.

In conclusion, we disclose the first automated glycan assembly of oligogalactofuranosides. The identification of differentially protected benzoyl substituted galactofuranose thioglycoside building blocks was key to the successful automated synthesis of the glycans as long as 20-mers found on the cell surface of bacteria. The building blocks will be useful for the construction of many other oligofuranosides.

\section{EXPERIMENTAL SECTION}

General Information. All chemicals used were reagent grade and used as supplied unless otherwise noted. Automated syntheses were performed on a home-built synthesizer developed at the Max Planck Institute of Colloids and Interfaces. ${ }^{15}$ Merrifield resin LL (100-200 mesh, Novabiochem) was modified and used as solid support. ${ }^{16}$ Analytical thin-layer chromatography (TLC) was performed on Merck silica gel $60 \mathrm{~F}_{254}$ plates $(0.25 \mathrm{~mm})$. Compounds were visualized by UV irradiation or dipping the plate in a $p$-anisaldehyde (PAA) solution. Flash column chromatography was carried out by using forced flow of the indicated solvent on Fluka Kieselgel $60 \mathrm{M}$ $(0.04-0.063 \mathrm{~mm})$. Analysis and purification by normal and reverse phase HPLC was performed using an Agilent 1200 series. Products were lyophilized using a Christ Alpha 2-4 LD plus freeze-dryer. ${ }^{1} \mathrm{H}$, ${ }^{13} \mathrm{C}$, and HSQC NMR spectra were recorded on a Varian 400-MR (400 MHz), Varian 600-MR $(600 \mathrm{MHz})$, or Bruker Biospin AVANCE700 $(700 \mathrm{MHz})$ spectrometer. Spectra were recorded in $\mathrm{CDCl}_{3}$ by using the solvent residual peak chemical shift as the internal standard $\left(\mathrm{CDCl}_{3}: 7.26 \mathrm{ppm}{ }^{1} \mathrm{H}, 77.16 \mathrm{ppm}{ }^{13} \mathrm{C}\right)$ or in $\mathrm{D}_{2} \mathrm{O}$ using the solvent as the internal standard in ${ }^{1} \mathrm{H}$ NMR $\left(\mathrm{D}_{2} \mathrm{O}: 4.79 \mathrm{ppm}{ }^{1} \mathrm{H}\right)$ unless otherwise stated. High resolution mass spectra were obtained using a 6210 ESI-TOF mass spectrometer (Agilent) and a MALDITOF Autoflex (Bruker). MALDI and ESI mass spectra were run on IonSpec Ultima instruments.
Automated Synthesis. Solvents used for dissolving building blocks and preparing the activator, TMSOTf, and capping solutions were taken from an anhydrous solvent system (jcmeyer-solvent systems). Other solvents used were HPLC grade. The building blocks were coevaporated three times with toluene and dried $2 \mathrm{~h}$ under a high vacuum before use. Activator, deprotection, acidic wash, capping, and building block solutions were freshly prepared and kept under argon during the automation run. All yields of products obtained by AGA were calculated based on resin loading. Resin loading was determined by performing one glycosylation (Module C) with ten equivalents of building block followed by DBU promoted Fmoccleavage and determination of dibenzofulvene production by measuring its UV absorbance.

Preparation of Stock Solutions. ${ }^{17}$ Building Block. Building block was dissolved in $1 \mathrm{~mL}$ dichloromethane (DCM).

Activator Solution. Recrystallized NIS (1.56 g) was dissolved in 60 $\mathrm{mL}$ of a 2:1 mixture of anhydrous $\mathrm{CH}_{2} \mathrm{Cl}_{2}$ and anhydrous dioxane. Then triflic acid $(67 \mu \mathrm{L})$ was added. The solution was kept at $0{ }^{\circ} \mathrm{C}$ for the duration of the automation run.

Fmoc Deprotection Solution. A solution of $20 \%$ piperidine in dimethylformamide (DMF) (v/v) was prepared, or a solution of $5 \%$ DBU in dichloromethane $\left(\mathrm{CH}_{2} \mathrm{Cl}_{2}\right)(\mathrm{v} / \mathrm{v})$ was prepared.

TMSOTf Solution. Trimethylsilyl trifluoromethanesulfonate (TMSOTf) $(0.9 \mathrm{~mL})$ was added to DCM $(80 \mathrm{~mL})$.

Capping Solution. A solution of $10 \%$ acetic anhydride $\left(\mathrm{Ac}_{2} \mathrm{O}\right)$ and $2 \%$ methanesulfunic acid $(\mathrm{MsOH})$ in anhydrous $\mathrm{CH}_{2} \mathrm{Cl}_{2}(\mathrm{v} / \mathrm{v})$ was prepared.

Modules for Automated Synthesis. Module A: Resin Preparation for Synthesis (20 min). All automated syntheses were performed on $140 \mu \mathrm{mol}$ scale $(40 \mathrm{mg})$. Resin was placed in the reaction vessel and swollen in DCM for $20 \mathrm{~min}$ at room temperature prior to synthesis. During this time, all reagent lines required for the synthesis were washed and primed. Before the first glycosylation, the resin was washed with the DMF, tetrahydrofuran (THF), and $\mathrm{CH}_{2} \mathrm{Cl}_{2}$ (three times each with $2 \mathrm{~mL}$ for $25 \mathrm{~s}$ ). This step is conducted as the first step for every synthesis.

Module B: Acidic Wash with TMSOTf Solution $(20 \mathrm{~min})$. The resin was swollen in $\mathrm{CH}_{2} \mathrm{Cl}_{2}(2 \mathrm{~mL})$ and the temperature of the reaction vessel was adjusted to $-20{ }^{\circ} \mathrm{C}$. Upon reaching the temperature, TMSOTf solution $(1 \mathrm{~mL})$ was added dropwise to the reaction vessel. After bubbling for argon $3 \mathrm{~min}$, the acidic solution was drained and the resin was washed with $2 \mathrm{~mL} \mathrm{CH}_{2} \mathrm{Cl}_{2}$ for $25 \mathrm{~s}$.

Module C: Thioglycoside Glycosylation (20-60 min). The building block solution (0.095-0.123 mmol (5-6.5 equiv) of BB in $1 \mathrm{~mL}$ of $\mathrm{CH}_{2} \mathrm{Cl}_{2}$ per glycosylation) was delivered to the reaction vessel. After the set temperature $\left(-20{ }^{\circ} \mathrm{C}\right)$ was reached, the reaction was started by dropwise addition of the activator solution $(1.0 \mathrm{~mL}$, excess). The glycosylation was performed by increasing the temperature to $0{ }^{\circ} \mathrm{C}$ for $20-60 \mathrm{~min}$ (depending on oligosaccharide length). After completion of the reaction, the solution is drained and the resin was washed with $\mathrm{CH}_{2} \mathrm{Cl}_{2}, \mathrm{CH}_{2} \mathrm{Cl}_{2}$ :dioxane $(1: 2,3 \mathrm{~mL}$ for 20 s) and $\mathrm{CH}_{2} \mathrm{Cl}_{2}$ (twice, each with $2 \mathrm{~mL}$ for $25 \mathrm{~s}$ ). The temperature of the reaction vessel is increased to $25{ }^{\circ} \mathrm{C}$ for the next module.

Module D: Capping (30 min). The resin was washed with DMF (twice with $2 \mathrm{~mL}$ for $25 \mathrm{~s}$ ) and the temperature of the reaction vessel

Scheme 5. Synthesis of $\beta$-(1 $\rightarrow 5)$ - and $\beta$-(1 $\rightarrow$ 6)-Linked Linear Galactan 20-mer 1

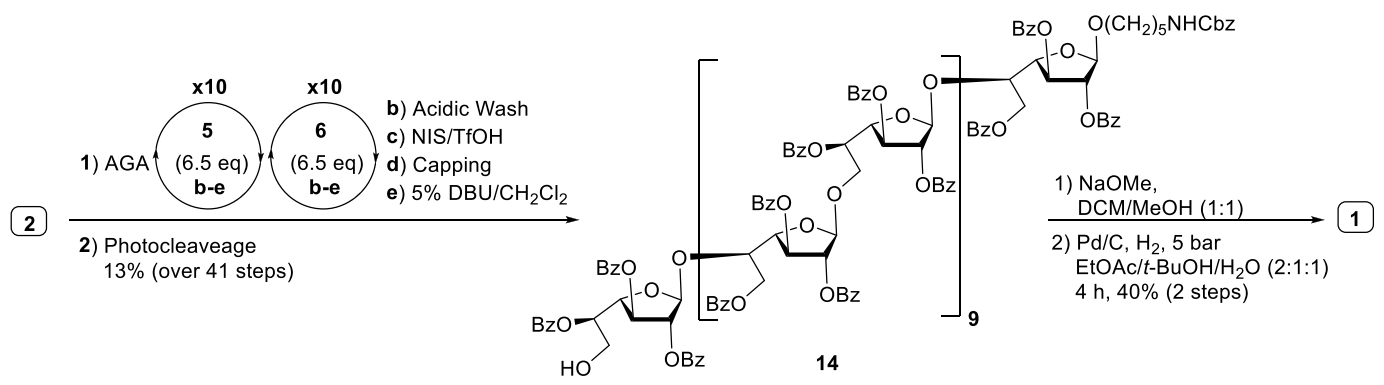


was adjusted to $25{ }^{\circ} \mathrm{C}$. Pyridine solution ( $2 \mathrm{~mL}, 10 \%$ in DMF) was delivered into the reaction vessel. After $1 \mathrm{~min}$, the reaction solution was drained and the resin washed with $\mathrm{CH}_{2} \mathrm{Cl}_{2}$ (three times with 3 $\mathrm{mL}$ for $25 \mathrm{~s})$. The capping solution $(4 \mathrm{~mL})$ was delivered into the reaction vessel. After $20 \mathrm{~min}$, the reaction solution was drained and the resin washed with $\mathrm{CH}_{2} \mathrm{Cl}_{2}$ (three times with $3 \mathrm{~mL}$ for $25 \mathrm{~s}$ ).

Module E: Fmoc Deprotection (14 min). The resin was washed with DMF (three times with $2 \mathrm{~mL}$ for $25 \mathrm{~s}$ ) and the temperature of the reaction vessel was adjusted to $25^{\circ} \mathrm{C}$. Fmoc deprotection solution $(2 \mathrm{~mL})$ was delivered into the reaction vessel. After $5 \mathrm{~min}$, the reaction solution was drained and the resin washed with DMF (three times with $3 \mathrm{~mL}$ for $25 \mathrm{~s}$ ) and $\mathrm{CH}_{2} \mathrm{Cl}_{2}$ (five times each with $2 \mathrm{~mL}$ for $25 \mathrm{~s}$ ). The temperature of the reaction vessel is decreased to $-20{ }^{\circ} \mathrm{C}$ for the next module.

Postsynthesizer Manipulations. Cleavage from Solid Support. After automated synthesis, the oligosaccharides were cleaved from the solid support using a continuous-flow photo reactor as described previously. ${ }^{11 \mathrm{c}, 18}$

Purification. Solvent was evaporated in vacuo and the crude products were dissolved in a 1:1 mixture of hexane and ethyl acetate and analyzed using analytical HPLC (DAD1F, $280 \mathrm{~nm}$ ). Pure compounds were afforded by preparative HPLC (Agilent 1200 Series spectrometer).

Method A. (YMC-Diol-300 column, $150 \times 4.6 \mathrm{~mm}$ ) flow rate of $1.0 \mathrm{~mL} / \mathrm{min}$ with $\mathrm{Hex}-20 \%$ EtOAc as eluents [isocratic 20\% EtOAc (5 min), linear gradient to $60 \%$ EtOAc ( $5 \mathrm{~min}$ ), linear gradient to $60 \%$ EtOAc (30 min), linear gradient to $100 \%$ EtOAc (5 min)].

Method B. (Synergi Hydro RP18 column, $250 \times 10 \mathrm{~mm}$ ) flow rate of $4.0 \mathrm{~mL} / \mathrm{min}$ with water $(0.1 \%$ formic acid) as eluents [isocratic (5 $\mathrm{min}$ ), linear gradient to $10 \% \mathrm{ACN}$ (30 min), linear gradient to $100 \%$ $\operatorname{ACN}(5 \mathrm{~min})]$.

(2S,3R,4R,5R)-2-((5-(tert-Butyl)-2-methylphenyl)thio)-5-((R)-2,2dimethyl-1,3-dioxolan-4-yl)tetrahydrofuran-3,4-diol (7). Compound $7(30.0 \mathrm{~g})$ was prepared in 6 steps from D-Galactose $(75.0$ $\mathrm{g}, 416.29 \mathrm{mmol})$ following the literature procedures ${ }^{7 \mathrm{a}, 13}$ as a light yellow sticky liquid.

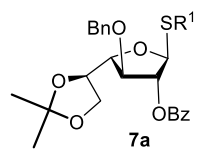

(2S,3R,4R,5R)-4-(Benzyloxy)-2-((5-(tert-butyl)-2-methylphenyl)thio)-5-((R)-2,2-dimethyl-1,3-dioxolan-4-yl)tetrahydrofuran-3-yl benzoate (7a). To a stirred solution of $7^{13}(10.0 \mathrm{~g}, 26.14 \mathrm{mmol})$ in pyridine $/ \mathrm{CH}_{2} \mathrm{Cl}_{2}(60 \mathrm{~mL} / 600 \mathrm{~mL})$ was added PhCOCl $(3.34 \mathrm{~mL}$, $28.74 \mathrm{mmol}$ ) dropwise at $0{ }^{\circ} \mathrm{C}$, and the resulting mixture was gradually warmed to room temperature. The reaction mixture was stirred for $4 \mathrm{~h}$ at the same temperature, at the end of which time TLC indicated it was finished. The reaction was quenched with $\mathrm{MeOH}$, diluted with $\mathrm{CH}_{2} \mathrm{Cl}_{2}$, and the mixture was washed with $1 \mathrm{M} \mathrm{HCl}$, aq. $\mathrm{NaHCO}_{3}$, brine and dried over $\mathrm{MgSO}_{4}$. The combined organic layers were filtered, and concentrated. The residue was purified by silica gel column chromatography (ethyl acetate/ $n$-hexanes: $20 / 80$ ) to afford corresponding 2-O-benzoylated derivative in $46 \%$ yield $(5.0 \mathrm{~g})$ lightbrown sticky liquid.

2-O-Benzoylated derivative $(5.0 \mathrm{~g}, 10.27 \mathrm{mmol})$ from the above was dissolve in anhydrous $\mathrm{CH}_{2} \mathrm{Cl}_{2}$ containing $4 \AA$ molecular sieves, was added silver oxide $(4.76 \mathrm{~g}, 20.54 \mathrm{mmol})$ and $\mathrm{BnBr}(1.46 \mathrm{~mL}$, $12.32 \mathrm{mmol})$ at $0{ }^{\circ} \mathrm{C}$ under nitrogen atmosphere. The reaction temperature was gradually warmed to room temperature, the solution was kept stirring for $48 \mathrm{~h}$. After completion of the reaction as indicated by TLC, the resulting mixture was filtered through a pad of Celite, the filtrate was concentrated in a vacuum, the crude residue was purified (ethyl acetate/n-hexanes: 20/80) to yield titled compound $7 \mathrm{a}$ in $78 \%$ yield $(4.62 \mathrm{~g})$ as a thick syrup. ${ }^{1} \mathrm{H}$ NMR $\left(400 \mathrm{MHz}, \mathrm{CDCl}_{3}\right) \delta 8.02-7.91(\mathrm{~m}, 2 \mathrm{H}), 7.59-7.48(\mathrm{~m}, 2 \mathrm{H}), 7.38$ $(\mathrm{t}, J=7.8 \mathrm{~Hz}, 2 \mathrm{H}), 7.33-7.29(\mathrm{~m}, 2 \mathrm{H}), 7.28-7.12(\mathrm{~m}, 4 \mathrm{H}), 7.06(\mathrm{~d}$, $J=8.2 \mathrm{~Hz}, 1 \mathrm{H}), 5.52(\mathrm{~d}, J=1.4 \mathrm{~Hz}, 2 \mathrm{H}), 4.81(\mathrm{~d}, J=11.9 \mathrm{~Hz}, 1 \mathrm{H})$, $4.57(\mathrm{~d}, J=11.9 \mathrm{~Hz}, 1 \mathrm{H}), 4.37(\mathrm{t}, J=5.6 \mathrm{~Hz}, 1 \mathrm{H}), 4.19(\mathrm{td}, J=6.7$,
$5.4 \mathrm{~Hz}, 1 \mathrm{H}), 3.93(\mathrm{dt}, J=5.6,1.3 \mathrm{~Hz}, 1 \mathrm{H}), 3.86-3.66(\mathrm{~m}, 2 \mathrm{H}), 2.37$ $(\mathrm{s}, 3 \mathrm{H}), 1.32(\mathrm{~s}, 3 \mathrm{H}), 1.26(\mathrm{~s}, 3 \mathrm{H}), 1.22(\mathrm{~s}, 9 \mathrm{H}) ;{ }^{13} \mathrm{C}\left\{{ }^{1} \mathrm{H}\right\}$ NMR $(100$ $\left.\mathrm{MHz}, \mathrm{CDCl}_{3}\right) \delta 165.4,149.6,137.8,137.2,133.6,132.3,131.5,130.0$, 129.9, 129.4, 128.6, 128.6, 128.3, 128.1, 125.4, 109.8, 91.4, 83.7, 82.8, 82.3, 75.4, 72.5, 65.5, 34.5, 31.4, 29.8, 26.4, 25.5, 20.6; ESI HR-MS $m / z[\mathrm{M}+\mathrm{Na}]^{+}$calcd. for $\mathrm{C}_{34} \mathrm{H}_{40} \mathrm{NaO}_{6} \mathrm{~S}: 599.2443$, found 599.2464.

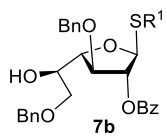

(2S,3R,4R,5R)-4-(Benzyloxy)-5-((R)-2-(benzyloxy)-1-hydroxyethyl)-2-((5-(tert-butyl)-2-methylphenyl)thio)tetrahydrofuran-3-yl benzoate (7b). Compound $7 \mathrm{a}(4.62 \mathrm{~g}, 8.01 \mathrm{mmol})$ was dissolved in $80 \%$ acetic acid in water and the mixture was stirred at $80^{\circ} \mathrm{C}$ for $4 \mathrm{~h}$. After completion of the reaction, the reaction mixture was concentrated and the residue was purified by column chromatography on silica gel (ethyl acetate/n-hexanes: 60/40) to give 5,6-diol 8 in $80 \%$ yield ( $3.44 \mathrm{~g})$ as a colorless syrup. Then, diol $(3.44 \mathrm{~g}, 6.41$ $\mathrm{mmol})$ was reacted with benzaldehyde dimethyl acetal $(1.15 \mathrm{~mL}, 7.69$ $\mathrm{mmol})$ using CSA $(0.22 \mathrm{~g}, 0.96 \mathrm{mmol})$ in the presence of $\mathrm{CH}_{3} \mathrm{CN}$ at room temperature. After completion of the reaction, $\mathrm{Et}_{3} \mathrm{~N}$ was added, concentrated and purified by silica gel column chromatography to afford transacetalation product in $72 \%$ yield $(2.88 \mathrm{~g})$ colorless liquid.

The compound $(2.88 \mathrm{~g}, 4.60 \mathrm{mmol})$ form the above step was dissolved in anhydrous $\mathrm{CH}_{2} \mathrm{Cl}_{2}$ containing $4 \AA$ molecular sieves powder and stirred at room temperature for $15 \mathrm{~min}$. After which, the reaction mixture was cooled to $-78{ }^{\circ} \mathrm{C}$ and then $\mathrm{Et}_{3} \mathrm{SiH}(7.44 \mathrm{~mL}$, $46.09 \mathrm{mmol}$ ) was added dropwise and stirred for $15 \mathrm{~min}$. Then, TFA $(3.52 \mathrm{~mL}, 46.09 \mathrm{mmol})$ was added and stirred for $15 \mathrm{~min}$, followed by TFAA $(0.12 \mathrm{~mL}, 0.92 \mathrm{mmol})$. The reaction mixture was stirred at $-78{ }^{\circ} \mathrm{C}$ for $45 \mathrm{~min}$, after which the reaction was removed from cooling bath and slowly brought to $0{ }^{\circ} \mathrm{C}$. After being stirred for $1.5 \mathrm{~h}$, the reaction was monitored by TLC, which indicated the completeness of the reaction. Then, the reaction mixture was filtered through a pad of Celite, the filtrate was washed with aq. $\mathrm{NaHCO}_{3}$, water, brine and concentrated in a vacuum, the crude residue was purified (ethyl acetate/ $n$-hexanes: $20 / 80$ ) to yield $7 \mathbf{b}$ in $82 \%$ yield $(2.36 \mathrm{~g})$ as colorless thick syrup. ${ }^{1} \mathrm{H}$ NMR $\left(400 \mathrm{MHz}, \mathrm{CDCl}_{3}\right) \delta$ 7.98-7.92 (m, 2H), 7.54-7.47 (m, 2H), $7.37(\mathrm{t}, J=7.8 \mathrm{~Hz}, 2 \mathrm{H})$, $7.30-7.27(\mathrm{~m}, 2 \mathrm{H}), 7.26-7.20(\mathrm{~m}, 7 \mathrm{H}), 7.18(\mathrm{~d}, J=6.8 \mathrm{~Hz}, 1 \mathrm{H})$, $7.13(\mathrm{dd}, J=8.0,2.1 \mathrm{~Hz}, 1 \mathrm{H}), 7.06(\mathrm{~d}, J=8.0 \mathrm{~Hz}, 1 \mathrm{H}), 5.54(\mathrm{~s}, 1 \mathrm{H})$, $5.51(\mathrm{t}, J=1.7 \mathrm{~Hz}, 1 \mathrm{H}), 4.77(\mathrm{~d}, J=11.9 \mathrm{~Hz}, 1 \mathrm{H}), 4.55(\mathrm{~d}, J=11.9$ $\mathrm{Hz}, 1 \mathrm{H}), 4.43(\mathrm{~d}, J=2.3 \mathrm{~Hz}, 2 \mathrm{H}), 4.39(\mathrm{dd}, J=5.9,3.0 \mathrm{~Hz}, 1 \mathrm{H}), 4.21$ (ddd, $J=5.8,1.9,0.9 \mathrm{~Hz}, 1 \mathrm{H}), 3.92(\mathrm{dt}, J=6.1,2.6 \mathrm{~Hz}, 1 \mathrm{H}), 3.61-$ $3.38(\mathrm{~m}, 2 \mathrm{H}), 2.34(\mathrm{~s}, 3 \mathrm{H}), 2.24(\mathrm{~d}, J=6.2 \mathrm{~Hz}, 1 \mathrm{H}), 1.20(\mathrm{~s}, 9 \mathrm{H})$.; ${ }^{13} \mathrm{C}\left\{{ }^{1} \mathrm{H}\right\}$ NMR $\left(100 \mathrm{MHz}, \mathrm{CDCl}_{3}\right) \delta 165.5,149.6,137.8,137.4$, $137.2,133.6,132.8,130.5,130.0,129.9,129.3,128.6,128.6,128.5$, 128.1, 128.0, 127.9, 127.8, 125.1, 91.4, 83.3, 82.5, 82.4, 73.5, 72.6, 71.8, 69.7, 34.5, 31.4, 20.5; HR-MS $\mathrm{m} / z[\mathrm{M}+\mathrm{Na}]^{+}$calcd. for $\mathrm{C}_{38} \mathrm{H}_{42} \mathrm{NaO}_{6} \mathrm{~S}$ : 649.2600 , found 649.2604 .

(2S, 3R, 4R,5R)-5-((R)-1-(((9H-Fluoren-9-yl)methoxy) carbonyl)oxy)-2-(benzyloxy)ethyl)-4-(benzyloxy)-2-((5-(tert-butyl)-2methylphenyl)thio)tetrahydrofuran-3-yl benzoate (3). To a stirred solution of $7 \mathbf{b}(2.36 \mathrm{~g}, 3.76 \mathrm{mmol})$ in anhydrous $\mathrm{CH}_{2} \mathrm{Cl}_{2}$ at $0{ }^{\circ} \mathrm{C}$, FmocCl $(2.43 \mathrm{~g}, 9.41 \mathrm{mmol})$ and pyridine $(1.51 \mathrm{~mL}, 18.82 \mathrm{mmol})$ were successively added and stirred at same temperature under ice bath for $4 \mathrm{~h}$. After completion of the reaction as indicated by TLC, the reaction mixture was diluted with $\mathrm{CH}_{2} \mathrm{Cl}_{2}$ and washed with $1 \mathrm{M}$ $\mathrm{HCl}$, aq. $\mathrm{NaHCO}_{3}$, brine. The combined organic layers were dried over $\mathrm{MgSO}_{4}$, concentrated and purified by column chromatography using silica gel (ethyl acetate/ $n$-hexanes: $20 / 80$ ) to give 3 in $87 \%$ yield $(2.78 \mathrm{~g})$ as a white foam. ${ }^{1} \mathrm{H}$ NMR $\left(400 \mathrm{MHz}, \mathrm{CDCl}_{3}\right) \delta 8.03-$ $7.94(\mathrm{~m}, 2 \mathrm{H}), 7.67(\mathrm{dd}, J=7.5,1.1 \mathrm{~Hz}, 2 \mathrm{H}), 7.58-7.49(\mathrm{~m}, 2 \mathrm{H}), 7.43$ (ddd, $J=9.5,7.0,1.4 \mathrm{~Hz}, 2 \mathrm{H}), 7.37-7.25(\mathrm{~m}, 6 \mathrm{H}), 7.21-7.09(\mathrm{~m}$, $11 \mathrm{H}), 7.04(\mathrm{~d}, J=8.0 \mathrm{~Hz}, 1 \mathrm{H}), 5.58(\mathrm{~s}, 1 \mathrm{H}), 5.54(\mathrm{t}, J=1.7 \mathrm{~Hz}, 1 \mathrm{H})$, $5.21(\mathrm{dt}, J=7.4,4.5 \mathrm{~Hz}, 1 \mathrm{H}), 4.77(\mathrm{~d}, J=11.8 \mathrm{~Hz}, 1 \mathrm{H}), 4.58(\mathrm{dd}, J=$ $5.8,4.0 \mathrm{~Hz}, 1 \mathrm{H}), 4.52(\mathrm{~d}, J=11.8 \mathrm{~Hz}, 1 \mathrm{H}), 4.48-4.36(\mathrm{~m}, 2 \mathrm{H}), 4.27$ $(\mathrm{dd}, J=10.3,7.7 \mathrm{~Hz}, 1 \mathrm{H}), 4.12(\mathrm{dd}, J=10.3,7.3 \mathrm{~Hz}, 1 \mathrm{H}), 4.08-4.01$ 
(m, $2 \mathrm{H}), 3.65(\mathrm{dd}, J=10.5,7.3 \mathrm{~Hz}, 1 \mathrm{H}), 3.58(\mathrm{dd}, J=10.6,4.7 \mathrm{~Hz}$, 1H), $2.34(\mathrm{~s}, 3 \mathrm{H}), 1.20(\mathrm{~s}, 9 \mathrm{H}) ;{ }^{13} \mathrm{C}\left\{{ }^{1} \mathrm{H}\right\} \operatorname{NMR}\left(100 \mathrm{MHz}, \mathrm{CDCl}_{3}\right) \delta$ $165.5,155.1,149.6,143.5,143.3,141.3,141.3,137.7,137.2,137.1$, $133.6,132.7,130.4,130.0,130.0,129.2,128.6,128.5,128.4,128.2$, $128.0,127.9,127.7,127.6,127.3,127.2,125.3,125.3,125.1,120.1$, 91.2, 83.1, 82.2, 81.1, 75.0, 73.3, 72.7, 70.2, 68.9, 46.7, 34.5, 31.4, 20.5; ESI HR-MS $m / z[\mathrm{M}+\mathrm{Na}]^{+}$calcd. for $\mathrm{C}_{53} \mathrm{H}_{52} \mathrm{NaO}_{8} \mathrm{~S}: 871.3281$, found 871.3297 .

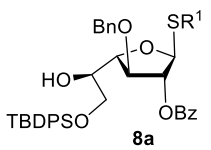

(2S,3R,4R,5R)-4-(Benzyloxy)-2-((5-(tert-butyl)-2-methylphenyl)thio)-5-((R)-2-((tert-butyldiphenylsilyl)oxy)-1-hydroxyethyl)tetrahydrofuran-3-yl benzoate (8a). Compound 8 (6.6 g, 12.29 mmol) was dissolved in anhydrous $\mathrm{CH}_{2} \mathrm{Cl}_{2}$ and cooled to $0{ }^{\circ} \mathrm{C}$. tertButyldiphenylsilyl chloride $(5.5 \mathrm{~mL}, 13.52 \mathrm{mmol})$ was added dropwise, followed by the addition imidazole $(2.09 \mathrm{~g}, 30.74 \mathrm{mmol})$. The reaction mixture was allowed to attain the room temperature under stirring, and the reaction was monitored by TLC, which indicated the completion after $3.5 \mathrm{~h}$. The reaction was diluted with $\mathrm{CH}_{2} \mathrm{Cl}_{2}$ and water, and the two layers were separated. The aqueous layer was thoroughly washed with $\mathrm{CH}_{2} \mathrm{Cl}_{2}$ and the combined organic layers were washed with brine solution and dried over anhydrous $\mathrm{MgSO}_{4}$. The solvent was evaporated to dryness and the residue was subjected to column chromatography (ethyl acetate/n-hexanes: $30 /$ 70 ) to yield corresponding silyl ether $8 \mathrm{a}$ in $82 \%$ yield $(7.81 \mathrm{~g})$ as a thick syrup. ${ }^{1} \mathrm{H}$ NMR $\left(400 \mathrm{MHz}, \mathrm{CDCl}_{3}\right) \delta 8.05-7.98(\mathrm{~m}, 2 \mathrm{H})$, $7.68-7.53(\mathrm{~m}, 6 \mathrm{H}), 7.50-7.27(\mathrm{~m}, 13 \mathrm{H}), 7.18(\mathrm{dd}, J=8.0,2.1 \mathrm{~Hz}$, $1 \mathrm{H}), 7.10(\mathrm{~d}, J=8.0 \mathrm{~Hz}, 1 \mathrm{H}), 5.63-5.52(\mathrm{~m}, 2 \mathrm{H}), 4.83(\mathrm{~d}, J=11.9$ $\mathrm{Hz}, 1 \mathrm{H}), 4.60(\mathrm{~d}, J=11.9 \mathrm{~Hz}, 1 \mathrm{H}), 4.50(\mathrm{dd}, J=5.9,2.8 \mathrm{~Hz}, 1 \mathrm{H})$, $4.23(\mathrm{dt}, J=5.7,1.4 \mathrm{~Hz}, 1 \mathrm{H}), 3.85(\mathrm{brs}, 1 \mathrm{H}), 3.79-3.65(\mathrm{~m}, 2 \mathrm{H})$, $2.38(\mathrm{~s}, 3 \mathrm{H}), 1.22(\mathrm{~s}, 9 \mathrm{H}), 1.06(\mathrm{~s}, 9 \mathrm{H}) ;{ }^{13} \mathrm{C}\left\{{ }^{1} \mathrm{H}\right\}$ NMR (100 MHz, $\mathrm{CDCl} 3) \delta 165.5,149.6,137.5,137.1,135.6,135.6,133.6,133.2$, $133.21,132.9,130.3,130.0,129.9,129.4,128.6,128.5,128.0,127.9$, 125.0, 91.6, 83.6, 82.5, 82.0, 72.6, 71.2, 65.3, 34.5, 31.4, 29.8, 26.9, 20.5,19.3; ESI HR-MS $m / z[\mathrm{M}+\mathrm{Na}]^{+}$calcd. for $\mathrm{C}_{47} \mathrm{H}_{54} \mathrm{NaO}_{6} \mathrm{SSi}$ : 797.3308, found 797.3293.

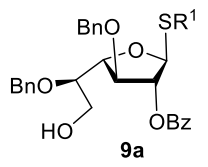

(2S,3R,4R,5R)-4-(Benzyloxy)-5-((R)-1-(benzyloxy)-2-hydroxyethyl)-2-((5-(tert-butyl)-2-methylphenyl)thio)tetrahydrofuran-3-yl benzoate $(9 a)$. To a stirred solution of silyl ether $8 \mathrm{a}(7.81 \mathrm{~g}, 10.08$ mmol) in anhydrous $\mathrm{CH}_{2} \mathrm{Cl}_{2}$ containing $4 \AA$ molecular sieves, was added silver oxide (4.66 g, $20.15 \mathrm{mmol})$ and $\mathrm{BnBr}(3.59 \mathrm{~mL}, 30.22$ $\mathrm{mmol})$ at $0{ }^{\circ} \mathrm{C}$ under nitrogen atmosphere. The reaction temperature was gradually warmed to room temperature, the solution was kept stirring for $48 \mathrm{~h}$. After completion of the reaction as indicated by TLC, the resulting mixture was filtered through a pad of Celite, the filtrate was concentrated in a vacuum, the crude residue was purified (ethyl acetate $/ n$-hexanes: $20 / 80$ ) to yield corresponding benzoylated derivative in $75 \%$ yield $(6.53 \mathrm{~g})$ as a light-yellow syrup. Then, the fully protected compound $(6.53 \mathrm{~g}, 7.55 \mathrm{mmol})$ was treated with $1 \mathrm{M} \mathrm{TBAF}$ $(17.48 \mathrm{~mL}, 60.37 \mathrm{mmol}$ ) buffered with $\mathrm{AcOH}(1.72 \mathrm{~mL}, 30.18$ $\mathrm{mmol}$ ) in anhydrous THF at $0{ }^{\circ} \mathrm{C}$ for $4.5 \mathrm{~h}$. After completion of the reaction as indicated by TLC, the reaction mixture was diluted with ethyl acetate and washed with water, brine and dried over anhydrous $\mathrm{MgSO}_{4}$. The combined organic layers were evaporated to dryness and subjected to column chromatography using silica gel (ethyl acetate $/ n$ hexanes: $30 / 70)$ to yield $9 \mathrm{a}$ in $65 \%$ yield $(3.07 \mathrm{~g})$ as a white foam. ${ }^{1} \mathrm{H}$ NMR (400 MHz, $\left.\mathrm{CDCl}_{3}\right) \delta 8.13-7.94(\mathrm{~m}, 2 \mathrm{H}), 7.65-7.57(\mathrm{~m}, 2 \mathrm{H})$, $7.51-7.41(\mathrm{~m}, 2 \mathrm{H}), 7.39-7.27(\mathrm{~m}, 5 \mathrm{H}), 7.22(\mathrm{ddt}, J=8.3,4.6,2.2$ $\mathrm{Hz}, 6 \mathrm{H}), 7.14(\mathrm{~d}, J=8.0 \mathrm{~Hz}, 1 \mathrm{H}), 5.65(\mathrm{q}, J=1.0 \mathrm{~Hz}, 1 \mathrm{H}), 5.56(\mathrm{t}, J$
$=1.6 \mathrm{~Hz}, 1 \mathrm{H}), 4.81(\mathrm{~d}, J=11.8 \mathrm{~Hz}, 1 \mathrm{H}), 4.65-4.56(\mathrm{~m}, 2 \mathrm{H}), 4.49$ $(\mathrm{dd}, J=20.0,11.7 \mathrm{~Hz}, 2 \mathrm{H}), 4.24-4.14(\mathrm{~m}, 1 \mathrm{H}), 3.87-3.62(\mathrm{~m}, 3 \mathrm{H})$, $2.43(\mathrm{~s}, 3 \mathrm{H}), 1.95(\mathrm{dd}, J=7.9,4.5 \mathrm{~Hz}, 1 \mathrm{H}), 1.28(\mathrm{~s}, 9 \mathrm{H}) ;{ }^{13} \mathrm{C}\left\{{ }^{1} \mathrm{H}\right\}$ NMR $\left(100 \mathrm{MHz}, \mathrm{CDCl}_{3}\right) \delta 165.5,149.7,138.0,137.2,137.2,133.6$, $132.6,130.2$, 130.1, 129.9, 129.3, 128.6, 128.6, 128.5, 128.4, 128.2, 128.1, 127.9, 125.2, 91.1, 83.1, 83.1, 82.5, 73.1, 72.5, 62.5, 34.5, 31.4, 20.5; ESI HR-MS $m / z[\mathrm{M}+\mathrm{Na}]^{+}$calcd. for $\mathrm{C}_{38} \mathrm{H}_{42} \mathrm{NaO}_{6} \mathrm{~S}: 649.2600$, found 649.2613 .

(2S,3R,4R,5R)-5-((R)-2-((((9H-Fluoren-9-yl)methoxy)carbonyl)oxy)-1-(benzyloxy)ethyl)-4-(benzyloxy)-2-((5-(tert-butyl)-2methylphenyl)thio)tetrahydrofuran-3-yl benzoate (4). To a stirred solution of $9 \mathrm{a}(3.0 \mathrm{~g}, 4.78 \mathrm{mmol})$ in anhydrous $\mathrm{CH}_{2} \mathrm{Cl}_{2}$ at $0{ }^{\circ} \mathrm{C}$, FmocCl $(3.09 \mathrm{~g}, 11.96 \mathrm{mmol})$ and pyridine $(1.92 \mathrm{~mL}, 23.93 \mathrm{mmol})$ were successively added and stirred at same temperature under ice bath for $4 \mathrm{~h}$. After completion of the reaction as indicated by TLC, the reaction mixture was diluted with $\mathrm{CH}_{2} \mathrm{Cl}_{2}$ and washed with $1 \mathrm{M}$ $\mathrm{HCl}$, aq. $\mathrm{NaHCO}_{3}$, brine. The combined organic layers were dried over $\mathrm{MgSO}_{4}$, concentrated and purified by column chromatography using silica gel (ethyl acetate/ $n$-hexanes: $20 / 80$ ) to give 4 in $74 \%$ yield $(3.0 \mathrm{~g})$ as a white foam. ${ }^{1} \mathrm{H}$ NMR $\left(400 \mathrm{MHz}, \mathrm{CDCl}_{3}\right) \delta 7.97-$ $7.90(\mathrm{~m}, 2 \mathrm{H}), 7.73-7.68(\mathrm{~m}, 2 \mathrm{H}), 7.57-7.47(\mathrm{~m}, 4 \mathrm{H}), 7.34(\mathrm{td}, J=$ 7.7, 3.2 Hz, 4H), 7.31-7.20 (m, 7H), 7.14-7.08 (m, 6H), $7.04(\mathrm{~d}, J=$ $8.0 \mathrm{~Hz}, 1 \mathrm{H}), 5.58(\mathrm{~s}, 1 \mathrm{H}), 5.49(\mathrm{t}, J=1.6 \mathrm{~Hz}, 1 \mathrm{H}), 4.72(\mathrm{~d}, J=11.9$ $\mathrm{Hz}, 1 \mathrm{H}), 4.59(\mathrm{~d}, J=11.4 \mathrm{~Hz}, 1 \mathrm{H}), 4.51(\mathrm{dd}, J=6.1,3.2 \mathrm{~Hz}, 1 \mathrm{H})$, $4.44-4.23(\mathrm{~m}, 6 \mathrm{H}), 4.15(\mathrm{t}, J=7.4 \mathrm{~Hz}, 1 \mathrm{H}), 4.07(\mathrm{dt}, J=6.1,1.3 \mathrm{~Hz}$, $1 \mathrm{H}), 3.80$ (ddd, $J=6.9,5.1,3.2 \mathrm{~Hz}, 1 \mathrm{H}), 2.33(\mathrm{~s}, 3 \mathrm{H}), 1.21(\mathrm{~s}, 9 \mathrm{H})$; ${ }^{13} \mathrm{C}\left\{{ }^{1} \mathrm{H}\right\}$ NMR $\left(100 \mathrm{MHz}, \mathrm{CDCl}_{3}\right) \delta 165.5,155.0,149.7,143.4$, 141.4, 137.69 137.4, 137.0, 133.5, 132.8, 130.1, 130.0, 129.3, 128.6, $128.6,128.4,128.4,128.3,128.1,128.0,127.9,127.3,127.3,125.3$, 125.0, 120.2, 91.3, 82.8, 82.7, 82.0, 77.3, 75.0, 73.7, 72.5, 70.0, 67.6, 46.7, 34.5, 31.4, 29.8, 20.5; ESI HR-MS $m / z[\mathrm{M}+\mathrm{Na}]^{+}$calcd. for $\mathrm{C}_{53} \mathrm{H}_{52} \mathrm{NaO}_{8} \mathrm{~S}$ : 871.3281, found 871.3293.

(2S,3R,4R,5R)-2-((5-(tert-Butyl)-2-methylphenyl)thio)-5-((R)-1,2dihydroxyethyl)tetrahydrofuran-3,4-diyl dibenzoate (11). ${ }^{33}$ To a solution of $7^{13}(5.0 \mathrm{~g}, 13.07 \mathrm{mmol})$ in pyridine was added $\mathrm{PhCOCl}$ $(3.34 \mathrm{~mL}, 28.75 \mathrm{mmol})$ dropwise at $0{ }^{\circ} \mathrm{C}$, and the resulting mixture was gradually warmed to room temperature. The reaction mixture was stirred for $4 \mathrm{~h}$ at the same temperature, at the end of which time TLC indicated it was finished. The reaction was quenched with $\mathrm{MeOH}$, diluted with $\mathrm{CH}_{2} \mathrm{Cl}_{2}$, and the mixture was washed with $1 \mathrm{M} \mathrm{HCl}$, aq. $\mathrm{NaHCO}_{3}$, brine and dried over $\mathrm{MgSO}_{4}$. The combined organic layers were filtered, and concentrated. The residue was purified by silica gel column chromatography (ethyl acetate $/ n$-hexanes: $20 / 80$ ) to afford corresponding $2,3-\mathrm{O}$-benzoylated derivative in $86 \%$ yield $(6.64 \mathrm{~g})$ as a glassy liquid.

To a stirred solution of 2,3-O-benzoylated derivative (6.64 g, 11.24 $\mathrm{mmol})$ in $80 \%$ aqueous acetic acid was stirred at $80^{\circ} \mathrm{C}$ for $5 \mathrm{~h}$. After completion of the reaction, the reaction mixture was concentrated and the residue was purified by column chromatography on silica gel (ethyl acetate/ $n$-hexanes: $60 / 40)$ to give 11 in $80 \%$ yield $(4.95 \mathrm{~g})$ as a colorless syrup. ${ }^{1} \mathrm{H}$ NMR $\left(400 \mathrm{MHz}, \mathrm{CDCl}_{3}\right) \delta 8.17-8.11(\mathrm{~m}, 2 \mathrm{H})$, 8.09-8.03 (m, 2H), 7.69-7.55 (m, 3H), 7.53-7.42 (m, 4H), 7.30$7.23(\mathrm{~m}, 1 \mathrm{H}), 7.18(\mathrm{~d}, J=8.0 \mathrm{~Hz}, 1 \mathrm{H}), 5.74(\mathrm{t}, J=1.6 \mathrm{~Hz}, 1 \mathrm{H}), 5.70$ $(\mathrm{dd}, J=4.3,1.5 \mathrm{~Hz}, 2 \mathrm{H}), 4.59$ (ddd $J=5.2,3.0,0.9 \mathrm{~Hz}, 1 \mathrm{H}), 4.18(\mathrm{q}$, $J=4.2 \mathrm{~Hz}, 1 \mathrm{H}), 3.96-3.70(\mathrm{~m}, 2 \mathrm{H}), 2.73(\mathrm{~d}, J=7.9 \mathrm{~Hz}, 1 \mathrm{H}), 2.46(\mathrm{~s}$, 3H), $1.30(\mathrm{~s}, 9 \mathrm{H}) ;{ }^{13} \mathrm{C}\left\{{ }^{1} \mathrm{H}\right\} \mathrm{NMR}\left(100 \mathrm{MHz}, \mathrm{CDCl}_{3}\right) \delta 166.1,165.4$, $149.9,137.6,133.9,133.8,131.9,131.0,130.3,130.2,130.0,129.0$, 129.0, 128.7, 128.7, 125.7, 91.4, 84.3, 82.1, 78.2, 77.3, 70.5, 64.4, 34.5, 31.4, 20.6; ESI HR-MS $m / z[\mathrm{M}+\mathrm{Na}]^{+}$calcd. for $\mathrm{C}_{31} \mathrm{H}_{34} \mathrm{NaO}_{7} \mathrm{~S}$ : 573.1923, found 573.1910 .

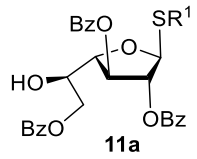

(2R,3R,4R,5S)-2-((R)-2-(Benzoyloxy)-1-hydroxyethyl)-5-((5-(tertbutyl)-2-methylphenyl)thio)tetrahydrofuran-3,4-diyl dibenzoate (11a). ${ }^{13}$ Compound 11 (2.77 g, $\left.5.03 \mathrm{mmol}\right)$ was dissolved in anhydrous $\mathrm{CH}_{2} \mathrm{Cl}_{2}$ and cooled to $-60{ }^{\circ} \mathrm{C}$. At this temperature, 
pyridine $(2.02 \mathrm{~mL}, 25.15 \mathrm{mmol})$ was added and stirred for $5 \mathrm{~min}$. Then, PhCOCl $(0.65 \mathrm{~mL}, 5.63 \mathrm{mmol})$ was added dropwise and stirred for $30 \mathrm{~min}$ at $-60^{\circ} \mathrm{C}$. The reaction progress was monitored by TLC. After $0.5 \mathrm{~h}$, the reaction was completed and $\mathrm{MeOH}$ was added to quench the reaction. The reaction mixture was diluted $\mathrm{CH}_{2} \mathrm{Cl}_{2}$ and washed with $1 \mathrm{M} \mathrm{HCl}$, aq. $\mathrm{NaHCO}_{3}$, brine and dried over $\mathrm{MgSO}_{4}$. The combined organic layers were filtered, and concentrated. The residue was purified by silica gel column chromatography (ethyl acetate/ $n$-hexanes: $20 / 80)$ to afford 11 a in $82 \%$ yield $(2.70 \mathrm{~g})$ as a light-brown sticky liquid. ${ }^{1} \mathrm{H}$ NMR $\left(400 \mathrm{MHz}, \mathrm{CDCl}_{3}\right) \delta 8.17-8.11$ $(\mathrm{m}, 2 \mathrm{H}), 8.08-7.98(\mathrm{~m}, 4 \mathrm{H}), 7.68-7.35(\mathrm{~m}, 10 \mathrm{H}), 7.24(\mathrm{dd}, J=8.0$, $2.1 \mathrm{~Hz}, 1 \mathrm{H}), 7.15(\mathrm{~d}, J=8.0 \mathrm{~Hz}, 1 \mathrm{H}), 5.78(\mathrm{t}, J=1.6 \mathrm{~Hz}, 1 \mathrm{H}), 5.77-$ $5.73(\mathrm{~m}, 2 \mathrm{H}), 4.67(\mathrm{dd}, J=4.6,2.3 \mathrm{~Hz}, 1 \mathrm{H}), 4.61-4.49(\mathrm{~m}, 2 \mathrm{H}), 4.45$ $(\mathrm{dd}, J=10.2,3.8 \mathrm{~Hz}, 1 \mathrm{H}), 2.66(\mathrm{~d}, J=7.8 \mathrm{~Hz}, 1 \mathrm{H}), 2.45(\mathrm{~s}, 3 \mathrm{H}), 1.29$ $(\mathrm{s}, 9 \mathrm{H}) ;{ }^{13} \mathrm{C}\left\{{ }^{1} \mathrm{H}\right\}$ NMR $\left(100 \mathrm{MHz}, \mathrm{CDCl}_{3}\right) \delta 166.5,166.1,165.4$, $149.9,137.5,133.8,133.7,133.2,131.9,131.0,130.2,130.2,130.0$, $129.8,129.0,129.0,128.7,128.7,128.5,125.6,91.7,83.2,82.1,78.3$, 77.3, 69.1, 66.0, 34.5, 31.4, 20.6;ESI HR-MS $m / z[\mathrm{M}+\mathrm{Na}]^{+}$calcd. for $\mathrm{C}_{38} \mathrm{H}_{38} \mathrm{NaO}_{8} \mathrm{~S}$ : 677.2185, found 677.2191.

$(2 R, 3 R, 4 R, 5 S)-2-((R)-1-((((9 H-F l u o r e n-9-y l)$ methoxy) carbonyl)oxy)-2-(benzoyloxy)ethyl)-5-((5-(tert-butyl)-2-methylphenyl)thio)tetrahydrofuran-3,4-diyl dibenzoate (5). To a stirred solution of $11 \mathrm{a}^{13}(2.7 \mathrm{~g}, 4.12 \mathrm{mmol})$ in anhydrous $\mathrm{CH}_{2} \mathrm{Cl}_{2}$ at $0{ }^{\circ} \mathrm{C}, \mathrm{FmocCl}$ $(2.66 \mathrm{~g}, 10.31 \mathrm{mmol})$ and pyridine $(1.66 \mathrm{~mL}, 20.614 \mathrm{mmol})$ were successively added and stirred at same temperature under ice bath for $4 \mathrm{~h}$. After completion of the reaction as indicated by TLC, the reaction mixture was diluted with $\mathrm{CH}_{2} \mathrm{Cl}_{2}$ and washed with $1 \mathrm{M} \mathrm{HCl}$, aq. $\mathrm{NaHCO}_{3}$, brine. The combined organic layers were dried over $\mathrm{MgSO}_{4}$, concentrated and purified by column chromatography using silica gel (ethyl acetate/ $n$-hexanes: $20 / 80$ ) to give 5 in $89 \%$ yield $(3.21 \mathrm{~g})$ as white foam: ${ }^{1} \mathrm{H}$ NMR $\left(400 \mathrm{MHz}, \mathrm{CDCl}_{3}\right) \delta 8.13$ (ddd, $J=$ 8.4, 2.4, $1.3 \mathrm{~Hz}, 4 \mathrm{H}), 7.98-7.92(\mathrm{~m}, 2 \mathrm{H}), 7.75(\mathrm{~d}, J=7.6 \mathrm{~Hz}, 2 \mathrm{H})$, $7.68(\mathrm{~d}, J=2.1 \mathrm{~Hz}, 1 \mathrm{H}), 7.65-7.58(\mathrm{~m}, 2 \mathrm{H}), 7.54-7.43(\mathrm{~m}, 5 \mathrm{H})$, $7.42-7.32(\mathrm{~m}, 4 \mathrm{H}), 7.31-7.19(\mathrm{~m}, 5 \mathrm{H}), 7.16(\mathrm{~d}, J=8.0 \mathrm{~Hz}, 1 \mathrm{H})$, $5.80(\mathrm{~d}, J=1.4 \mathrm{~Hz}, 2 \mathrm{H}), 5.77(\mathrm{dt}, J=7.8,3.9 \mathrm{~Hz}, 1 \mathrm{H}), 5.67(\mathrm{dt}, J=$ $4.8,1.3 \mathrm{~Hz}, 1 \mathrm{H}), 4.87(\mathrm{t}, J=4.3 \mathrm{~Hz}, 1 \mathrm{H}), 4.75(\mathrm{dd}, J=11.9,4.0 \mathrm{~Hz}$, $1 \mathrm{H}), 4.65(\mathrm{dd}, J=12.0,7.7 \mathrm{~Hz}, 1 \mathrm{H}), 4.38(\mathrm{dd}, J=10.4,8.1 \mathrm{~Hz}, 1 \mathrm{H})$, $4.25(\mathrm{dd}, J=10.4,7.3 \mathrm{~Hz}, 1 \mathrm{H}), 4.18-4.09(\mathrm{~m}, 1 \mathrm{H}), 2.46(\mathrm{~s}, 3 \mathrm{H})$, $1.30(\mathrm{~s}, 9 \mathrm{H}) ;{ }^{13} \mathrm{C}\left\{{ }^{1} \mathrm{H}\right\}$ NMR $\left(100 \mathrm{MHz}, \mathrm{CDCl}_{3}\right) \delta$ 166.0, 165.7, $165.4,155.0,149.9,143.5,143.1,141.3,141.2,137.4,133.8,133.7$, 133.2, 132.0, 130.8, 130.2, 130.1, 129.8, 129.5, 129.0, 128.9, 128.7, $128.6,128.4,128.0,127.9,127.3,127.3,125.5,125.4,125.3,120.1$, 120.1, 91.5, 82.0, 81.6, 77.8, 77.3, 74.2, 70.6, 63.4, 46.6, 34.5, 31.4, 20.6; ESI HR-MS $m / z[M+N a]^{+}$calcd. for $\mathrm{C}_{53} \mathrm{H}_{48} \mathrm{NaO}_{10} \mathrm{~S}$ : 899.2866, found 899.2877 .

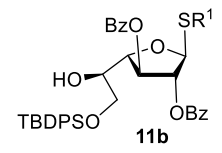

(2S,3R,4R,5R)-2-((5-(tert-Butyl)-2-methylphenyl)thio)-5-((R)-2((tert-butyldiphenylsilyl)oxy)-1-hydroxyethyl)tetrahydrofuran-3,4diyl dibenzoate (11b). Compound 11 (2.5 g, $4.54 \mathrm{mmol}$ ) was dissolved in anhydrous $\mathrm{CH}_{2} \mathrm{Cl}_{2}$ and cooled to $0{ }^{\circ} \mathrm{C}$. tertButyldiphenylsilyl chloride $(1.29 \mathrm{~mL}, 4.99 \mathrm{mmol})$ was added dropwise, followed by the addition imidazole $(0.77 \mathrm{~g}, 11.35 \mathrm{mmol})$. The reaction mixture was allowed to attain the room temperature under stirring, and the reaction was monitored by TLC, which indicated the completion after $3.5 \mathrm{~h}$. The reaction was diluted with $\mathrm{CH}_{2} \mathrm{Cl}_{2}$ and water, and the two layers were separated. The aqueous layer was thoroughly washed with $\mathrm{CH}_{2} \mathrm{Cl}_{2}$ and the combined organic layers were washed with brine solution and dried over anhydrous $\mathrm{MgSO}_{4}$. The solvent was evaporated to dryness and the residue was subjected to column chromatography (ethyl acetate/n-hexanes: $30 /$ $70)$ to yield corresponding silyl ether $\mathbf{1 1 b}$ in $85 \%$ yield $(3.04 \mathrm{~g})$ as a colorless liquid: ${ }^{1} \mathrm{H}$ NMR $\left(400 \mathrm{MHz}, \mathrm{CDCl}_{3}\right) \delta 8.17-8.11(\mathrm{~m}, 2 \mathrm{H})$, $8.08-8.02(\mathrm{~m}, 2 \mathrm{H}), 7.68-7.54(\mathrm{~m}, 7 \mathrm{H}), 7.50(\mathrm{t}, J=7.8 \mathrm{~Hz}, 2 \mathrm{H})$, $7.46-7.36(\mathrm{~m}, 4 \mathrm{H}), 7.32(\mathrm{td}, J=7.0,1.3 \mathrm{~Hz}, 4 \mathrm{H}), 7.21(\mathrm{dd}, J=8.0$, $2.1 \mathrm{~Hz}, 1 \mathrm{H}), 7.13(\mathrm{~d}, J=8.0 \mathrm{~Hz}, 1 \mathrm{H}), 5.75(\mathrm{ddd}, J=5.1,2.0,0.9 \mathrm{~Hz}$,
$1 \mathrm{H}), 5.72(\mathrm{t}, J=1.8 \mathrm{~Hz}, 1 \mathrm{H}), 5.70(\mathrm{~d}, J=1.7 \mathrm{~Hz}, 1 \mathrm{H}), 4.68(\mathrm{dd}, J=$ 5.1, $2.4 \mathrm{~Hz}, 1 \mathrm{H}), 4.18(\mathrm{qd}, J=6.7,2.5 \mathrm{~Hz}, 1 \mathrm{H}), 3.90-3.71(\mathrm{~m}, 2 \mathrm{H})$, $2.49(\mathrm{~d}, J=6.7 \mathrm{~Hz}, 1 \mathrm{H}), 2.41(\mathrm{~s}, 3 \mathrm{H}), 1.23(\mathrm{~s}, 9 \mathrm{H}), 1.04(\mathrm{~s}, 9 \mathrm{H})$; ${ }^{13} \mathrm{C}\left\{{ }^{1} \mathrm{H}\right\}$ NMR $\left(100 \mathrm{MHz}, \mathrm{CDCl}_{3}\right) \delta 165.8,165.4,149.7,137.2$, 135.6, 135.6, 133.6, 133.6, 133.2, 133.1, 132.4, 130.4, 130.1, 130.1, $130.0,129.9,129.8,129.3,129.1,128.6,128.6,127.8,125.2$, 91.5, 82.3, 82.2, 78.2, 77.3, 71.1, 65.0, 34.5, 31.4, 26.9, 20.6, 19.3; ESI HRMS $m / z[\mathrm{M}+\mathrm{Na}]^{+}$calcd. for $\mathrm{C}_{47} \mathrm{H}_{52} \mathrm{NaO}_{7} \mathrm{SSi}$ : 811.3101, found 811.3105 .

$(2 R, 3 R, 4 R, 5 S)-2-((R)-2-((((9 H-F l u o r e n-9-y l)$ methoxy $)$ carbonyl)oxy)-1-(benzoyloxy)ethyl)-5-((5-(tert-butyl)-2-methylphenyl)thio)tetrahydrofuran-3,4-diyl dibenzoate (6). To a solution of $11 \mathrm{~b}(3.0 \mathrm{~g}$, $3.80 \mathrm{mmol})$ in pyridine $(30 \mathrm{~mL})$ was added $\mathrm{PhCOCl}(0.66 \mathrm{~mL}, 5.70$ mmol) dropwise at $0{ }^{\circ} \mathrm{C}$, and the resulting mixture was gradually warmed to room temperature. The reaction mixture was stirred for 4 $h$ at the same temperature, at the end of which time TLC indicated it was finished. The reaction was quenched with $\mathrm{MeOH}$, diluted with $\mathrm{CH}_{2} \mathrm{Cl}_{2}$, and the mixture was washed with $1 \mathrm{M} \mathrm{HCl}$, aq. $\mathrm{NaHCO}_{3}$, brine and dried over $\mathrm{MgSO}_{4}$. The combined organic layers were filtered, and concentrated. The residue was purified by silica gel column chromatography (ethyl acetate/ $n$-hexanes: 20/80) to afford corresponding $2,3,5$-O-benzoylated derivative in $78 \%$ yield $(2.64 \mathrm{~g})$ as a light-brown sticky liquid.

To a stirred solution of 2,3,5-O-benzoylated derivative ( $2.64 \mathrm{~g}, 2.95$ $\mathrm{mmol})$ in anhydrous THF/Py at $0{ }^{\circ} \mathrm{C}, 30 \%$ HF.Py $(2.66 \mathrm{~mL}, 29.55$ $\mathrm{mmol}$ ) was added and stirred for $3.5 \mathrm{~h}$. After completion of the reaction as indicated by TLC, the reaction was diluted with ethyl acetate, aq. $\mathrm{NaHCO}_{3}$ was added to quench the excess of acid and the two layers were separated. The organic portion was washed with $1 \mathrm{M}$ $\mathrm{HCl}$, aq. $\mathrm{NaHCO}_{3}$, brine. The combined organic layers were dried over $\mathrm{MgSO}_{4}$, concentrated and purified (ethyl acetate/n-hexanes: 60/ $40)$ to afford corresponding $6-O$-alcohol in $71 \%$ yield $(1.37 \mathrm{~g})$ as a light yellow liquid.

The 6-O-alcohol $(1.37 \mathrm{~g}, 2.09 \mathrm{mmol})$ from above step was dissolved in anhydrous $\mathrm{CH}_{2} \mathrm{Cl}_{2}$ at $0{ }^{\circ} \mathrm{C}, \mathrm{FmocCl}(1.35 \mathrm{~g}, 5.23 \mathrm{mmol})$ and pyridine $(0.84 \mathrm{~mL}, 10.46 \mathrm{mmol})$ were successively added and stirred at same temperature under ice bath for $4 \mathrm{~h}$. After completion of the reaction as indicated by TLC, the reaction mixture was diluted with $\mathrm{CH}_{2} \mathrm{Cl}_{2}$ and washed with $1 \mathrm{M} \mathrm{HCl}$, aq. $\mathrm{NaHCO}_{3}$, brine. The combined organic layers were dried over $\mathrm{MgSO}_{4}$, concentrated and purified by column chromatography using silica gel (ethyl acetate/ $n$ hexanes: $20 / 80)$ to give 6 in $80 \%$ yield $(1.46 \mathrm{~g})$ as a white foam: ${ }^{1} \mathrm{H}$ NMR $\left(400 \mathrm{MHz}, \mathrm{CDCl}_{3}\right) \delta 8.10$ (ddtd, $J=14.0,7.5,1.3,0.6 \mathrm{~Hz}$, $4 \mathrm{H}), 7.93-7.89(\mathrm{~m}, 2 \mathrm{H}), 7.74(\mathrm{dt}, J=7.6,0.8 \mathrm{~Hz}, 2 \mathrm{H}), 7.66(\mathrm{t}, J=$ $1.7 \mathrm{~Hz}, 1 \mathrm{H}), 7.64-7.57(\mathrm{~m}, 1 \mathrm{H}), 7.54(\mathrm{dddt}, J=6.7,3.8,2.1,0.8 \mathrm{~Hz}$, $3 \mathrm{H}), 7.52-7.43(\mathrm{~m}, 3 \mathrm{H}), 7.42-7.32(\mathrm{~m}, 3 \mathrm{H}), 7.32-7.29(\mathrm{~m}, 1 \mathrm{H})$, $7.28(\mathrm{dt}, J=2.4,1.0 \mathrm{~Hz}, 1 \mathrm{H}), 7.26(\mathrm{~d}, J=0.4 \mathrm{~Hz}, 2 \mathrm{H}), 7.25-7.21(\mathrm{~m}$, $2 \mathrm{H}), 7.15$ (ddd, $J=8.0,1.1,0.6 \mathrm{~Hz}, 1 \mathrm{H}), 6.09-6.01(\mathrm{~m}, 1 \mathrm{H}), 5.78$ $(\mathrm{dq}, J=1.5,0.8 \mathrm{~Hz}, 1 \mathrm{H}), 5.71(\mathrm{td}, J=1.6,1.0 \mathrm{~Hz}, 1 \mathrm{H}), 5.65(\mathrm{ddq}, J=$ $4.0,1.5,0.8 \mathrm{~Hz}, 1 \mathrm{H}), 4.92$ (tdd, $J=4.0,1.7,0.8 \mathrm{~Hz}, 1 \mathrm{H}), 4.73-4.52$ (m, 2H), 4.43-4.31 (m, 1H), 4.30-4.08 (m, 2H), $2.46(\mathrm{~s}, 3 \mathrm{H}), 1.26$ $(\mathrm{s}, 9 \mathrm{H}) ;{ }^{13} \mathrm{C}\left\{{ }^{1} \mathrm{H}\right\}$ NMR $\left(100 \mathrm{MHz}, \mathrm{CDCl}_{3}\right) \delta 165.8,165.6,165.4$, $154.9,149.9,143.4,143.3,141.3,137.3,133.7,133.5,133.4,132.1$, $130.6,130.2,130.0,129.4,129.0,128.9,128.6,128.5,127.9,127.9$, $127.3,127.2,125.4,125.4,125.3,120.0,91.5,82.6,81.5,77.9,77.3$, 70.3, 70.2, 66.3, 46.6, 34.5, 31.4, 20.5; ESI HR-MS $m / z[\mathrm{M}+\mathrm{Na}]^{+}$ calcd. for $\mathrm{C}_{53} \mathrm{H}_{48} \mathrm{NaO}_{10} \mathrm{~S}$ : 899.2866, found 899.2869.

Analytical Data for 20-mer Oligogalactofuranoside (14). Sticky solid (Yield: $17 \mathrm{mg}, 13 \%$ over 41 steps). ${ }^{1} \mathrm{H}$ NMR (700 $\mathrm{MHz}$, $\left.\mathrm{CDCl}_{3}\right) \delta 8.04-7.80(\mathrm{~m}, 85 \mathrm{H}), 7.76-7.51(\mathrm{~m}, 45 \mathrm{H}), 7.49-7.43(\mathrm{~m}$, $14 \mathrm{H}), 7.42-7.30(\mathrm{~m}, 52 \mathrm{H}), 7.23(\mathrm{t}, J=7.6 \mathrm{~Hz}, 12 \mathrm{H}), 7.19-7.01(\mathrm{~m}$, $75 \mathrm{H}), 6.99-6.87(\mathrm{~m}, 22 \mathrm{H}), 5.85-5.55(\mathrm{~m}, 57 \mathrm{H}), 4.88-4.23(\mathrm{~m}$, $85 \mathrm{H}), 1.46(\mathrm{~m}, 4 \mathrm{H}), 1.37-1.32(\mathrm{~m}, 4 \mathrm{H}) ;{ }^{13} \mathrm{C}\left\{{ }^{1} \mathrm{H}\right\}$ NMR $(175 \mathrm{MHz}$, $\left.\mathrm{CDCl}_{3}\right) \delta 165.9,165.6,165.3,133.4,133.0,132.8,129.9,129.8,129.8$, 129.7, 129.1, 128.7, 128.6, 128.3, 128.0, 105.4, 83.6, 81.9, 72.9, 65.4, 32.0, 29.8, 29.5, 29.1, 23.4, 22.8, 14.2; (MALDI-TOF) $\mathrm{m} / z[\mathrm{M}+\mathrm{K}]^{+}$ calcd. for $\mathrm{C}_{553} \mathrm{H}_{459} \mathrm{KNO}_{163}$ : 9758.7296, found 9758.5120 .

20-mer Oligogalactofuranoside (1). Sodium methoxide in methanol $(0.5 \mathrm{M}, p \mathrm{H}=13)$ was added to a solution of protected oligosaccharide $(17 \mathrm{mg}) 14$ in methanol: $\mathrm{CH}_{2} \mathrm{Cl}_{2}(1: 1)$, and stirred at 
room temperature for $16 \mathrm{~h}$, neutralized with Amberlite ion exchange $\left(\mathrm{H}^{+}\right)$resin, filtered and concentrated in vacuo and carried forward directly into hydrogenolysis without purification. The Zemplén methanolysis product was dissolved in EtOAc:t-BuOH: $\mathrm{H}_{2} \mathrm{O}$ (2:1:1) and transferred to cylindrical vials. $\mathrm{Pd}(\mathrm{OH})_{2} / \mathrm{C}(10 \%),(100 \mathrm{wt} \%)$ was added and the reaction mixture was stirred in hydrogen reactor with 5 bar pressure for $4 \mathrm{~h}$. The reaction mixture was filtered through a pad of Celite and washed with methanol and water. The filtrates were concentrated in vacuo and purified on size exclusion chromatography (Method B) Synergi Hydro RP18 column and lyophilized to give a pure compound 1 in $40 \%$ yield over 2 steps (2 $\mathrm{mg})$ as a white fluffy solid. Analytical data for 1 : ${ }^{1} \mathrm{H}$ NMR $(700 \mathrm{MHz}$, $\left.\mathrm{D}_{2} \mathrm{O}\right) \delta 5.38-5.13(\mathrm{~m}, 17 \mathrm{H}), 5.08-4.97(\mathrm{~m}, 3 \mathrm{H}), 4.34(\mathrm{~d}, J=3.4 \mathrm{~Hz}$, $2 \mathrm{H}), 4.21-4.12(\mathrm{~m}, 48 \mathrm{H}), 4.11-4.06(\mathrm{~m}, 8 \mathrm{H}), 4.03-3.96(\mathrm{~m}, 17 \mathrm{H})$, 3.92 (ddd, $J=14.3,8.5,3.2 \mathrm{~Hz}, 4 \mathrm{H}), 3.83(\mathrm{t}, J=4.8 \mathrm{~Hz}, 33 \mathrm{H}), 3.79-$ $3.59(\mathrm{~m}, 10 \mathrm{H}), 3.09-3.00(\mathrm{~m}, 2 \mathrm{H}), 1.80-1.63(\mathrm{~m}, 4 \mathrm{H}), 1.53-1.43$ $(\mathrm{m}, 2 \mathrm{H}) ;{ }^{13} \mathrm{C}\left\{{ }^{1} \mathrm{H}\right\}$ NMR $\left(175 \mathrm{MHz}, \mathrm{D}_{2} \mathrm{O}\right) \delta$ 107.2, 107.1, 107.0, 107.0, 106.9, 82.6, 82.5, 82.4, 81.4, 81.4, 81.3, 81.2, 81.0, 79.5, 76.6, 76.4, 76.0, 75.5, 70.6, 70.5, 68.1, 62.8, 62.8, 61.1, 60.9, 39.4, 28.1, 26.4, 22.2; (MALDI-TOF) $\mathrm{m} / z[\mathrm{M}+\mathrm{Na}]^{+}$calcd. for $\mathrm{C}_{125} \mathrm{H}_{213} \mathrm{NNaO}_{101}$ : 3367.1460, found 3367.1450.

\section{ASSOCIATED CONTENT}

\section{SI Supporting Information}

The Supporting Information is available free of charge at https://pubs.acs.org/doi/10.1021/acs.joc.1c00505.

Copies of ${ }^{1} \mathrm{H}$ NMR, ${ }^{13} \mathrm{C}$ NMR, HPLC chromatograms, and MALDI (PDF)

\section{AUTHOR INFORMATION}

\section{Corresponding Author}

Peter H. Seeberger - Department of Biomolecular Systems, Max-Planck-Institute of Colloids and Interfaces, 14476

Potsdam, Germany; Freie Universität Berlin, Institute of

Chemistry and Biochemistry, 14195 Berlin, Germany;

(1) orcid.org/0000-0003-3394-8466;

Email: peter.seeberger@mpikg.mpg.de

\section{Author}

Narayana Murthy Sabbavarapu - Department of Biomolecular Systems, Max-Planck-Institute of Colloids and Interfaces, 14476 Potsdam, Germany

Complete contact information is available at:

https://pubs.acs.org/10.1021/acs.joc.1c00505

\section{Notes}

The authors declare no competing financial interest.

\section{ACKNOWLEDGMENTS}

We gratefully acknowledge the generous financial support of the Max-Planck Society. All of the acknowledged work was performed at the Max Planck Institute of Colloids and Interfaces.

\section{REFERENCES}

(1) (a) WHO Report 2004, Global Tuberculosis Control, Surveillance, Planning; World Health Organization: Geneva, 2004. (b) Chiang, C.Y.; Yew, W. W. Multidrug-resistant and Extensively Drug-resistant Tuberculosis. Int. J. Tuberc. Lung Dis. 2009, 13, 304-311.

(2) Brennan, P. J.; Nikaido, H. The Envelope of Mycobacteria. Annu. Rev. Biochem. 1995, 64, 29-63.

(3) Alderwick, L. J.; Radmacher, E.; Seidel, M.; Gande, R.; Hitchen, P. G.; Morris, H. R.; Dell, A.; Sahm, H.; Eggeling, L.; Besra, G. S. Deletion of Cg-emb in Corynebacterianeae Leads to a Novel Truncated Cell Wall Arabinogalactan, whereas Inactivation of $\mathrm{Cg}$ -
ubiA Results in an Arabinan-deficient Mutant with a Cell Wall Galactan Core. J. Biol. Chem. 2005, 280, 32362-32371.

(4) (a) Chlubnova, I.; Legentil, L.; Dureau, R.; Pennec, A.; Almendros, M.; Daniellou, R.; Nugier-Chauvin, C.; Ferrieres, V. Specific and Non-specific Enzymes for Furanosyl-containing Conjugates: Biosynthesis, Metabolism, and Chemo-enzymatic Synthesis. Carbohydr. Res. 2012, 356, 44-61. (b) Lowary, T. L. Recent Progress Towards the Identification of Inhibitors of Mycobacterial Cell Wall Polysaccharide Biosynthesis. Mini-Rev. Med. Chem. 2003, 3, 689-702. (c) Pedersen, L. L.; Turco, S. J. Galactofuranose Metabolism: A Potential Target for Antimicrobial Chemotherapy. Cell. Mol. Life Sci. 2003, 60, 259-266. (d) Marino, C.; Gallo-Rodriguez, C.; de Lederkremer, R. M. In Glycans: Biochemistry, Characterization and Applications; Mora-Montes, H. M., Ed.; Nova Science Publishers, Inc.: Huntington, NY, 2012; p 207.

(5) Rose, N. L.; Completo, G. C.; Lin, S.-J.; McNeil, M.; Palcic, M. M.; Lowary, T. L. Expression, Purification, and Characterization of a Galactofuranosyltransferase Involved in Mycobacterium tuberculosis Arabinogalactan Biosynthesis. J. Am. Chem. Soc. 2006, 128, 67216729.

(6) Angala, S. K.; Joe, M.; McNeil, M. R.; Liav, A.; Lowary, T. L.; Jackson, M. Use of Synthetic Glycolipids to Probe the Number and Position of Arabinan Chains on Mycobacterial Arabinogalactan. ACS Chem. Biol. 2021, 16, 20-26.

(7) (a) Completo, G. C.; Lowary, T. L. Synthesis of Galactofuranose-Containing Acceptor Substrates for Mycobacterial Galactofuranosyltransferases. J. Org. Chem. 2008, 73, 4513-4525. (b) Joe, M.; Lowary, T. L. Synthesis of a Homologous Series of Galactofuranosecontaining Mycobacterial Arabinogalactan Fragments. Can. J. Chem. 2016, 94, 976-988.

(8) Wu, Y.; Xiong, D.-C.; Chen, S.-C.; Wang, Y.-S.; Ye, X.-S. Total Synthesis of Mycobacterial Arabinogalactan containing 92 Monosaccharide Units. Nat. Commun. 2017, 8, 4851.

(9) (a) Gandolfi-Donadío, L.; Gallo-Rodriguez, C.; De Lederkremer, R. Synthesis of a Tetrasaccharide Fragment of Mycobacterial Arabinogalactan. Carbohydr. Res. 2008, 343, 1870-1875. (b) Zhang, G.; Fu, M.; Ning, J. An Efficient and Concise Synthesis of a $\beta$-(1 $\rightarrow 6)$-linked D-galactofuranosyl Hexasaccharide. Carbohydr. Res. 2005, 340, 155-159. (c) Gandolfi-Donadío, L.; Gallo-Rodriguez, C.; De Lederkremer, R. Syntheses of $\beta$-D-Galf- $(1 \rightarrow 6)-\beta$-D-Galf- $(1 \rightarrow$ $5)$-D-Galf and $\beta$-D-Galf- $(1 \rightarrow 5)-\beta$-D-Galf- $(1 \rightarrow 6)$-D-Galf, Trisaccharide Units in the Galactan of Mycobacterium tuberculosis. J. Org. Chem. 2003, 68, 6928-6934. (d) Veeneman, G. H.; Notermans, S.; Liskamp, R. M. J.; van der Marel, G. A.; van Boom, J. H. SolidPhase Synthesis of a Naturally Occurring $\beta$ - $(1 \rightarrow 5)$-linked Dgalactofuranosyl Heptamer Containing the Artificial Linkage ARM L-homoserine. Tetrahedron Lett. 1987, 28, 6695-6698.

(10) Plante, O. J.; Palmacci, E. R.; Seeberger, P. H. Automated Solid-Phase Synthesis of Oligosaccharides. Science 2001, 291, 15231527.

(11) (a) Routenberg Love, K.; Seeberger, P. H. Automated SolidPhase Synthesis of Protected Tumor-Associated Antigen and Blood Group Determinant Oligosaccharides. Angew. Chem., Int. Ed. 2004, 43, 602-605. (b) Werz, D. B.; Castagner, B.; Seeberger, P. H. Automated Synthesis of the Tumor-Associated Carbohydrate Antigens Gb-3 and Globo-H: Incorporation of $\alpha$-Galactosidic Linkages. J. Am. Chem. Soc. 2007, 129, 2770-2771. (c) Naresh, K.; Schumacher, F.; Hahm, H. S.; Seeberger, P. H. Pushing the Limits of Automated Glycan Assembly: Synthesis of a 50mer Polymannoside. Chem. Commun. 2017, 53, 9085-9088. (d) Joseph, A. A.; PardoVargas, A.; Seeberger, P. H. Total Synthesis of Polysaccharides by Automated Glycan Assembly. J. Am. Chem. Soc. 2020, 142, 85618564.

(12) Kandasamy, J.; Hurevich, M.; Seeberger, P. H. Automated Solid Phase Synthesis of Oligoarabinofuranosides. Chem. Commun. 2013, 49, 4453-4455.

(13) Cattiaux, L.; Sendid, B.; Collot, M.; Machez, E.; Poulain, D.; Mallet, J.-M. Synthetic Biotinylated tetra $\beta-(1 \rightarrow 5)$-galactofuranoside 
for in vitro Aspergillosis Diagnosis. Bioorg. Med. Chem. 2011, 19, $547-555$.

(14) Taha, H. A.; Richards, M. R.; Lowary, T. L. Conformational Analysis of Furanoside-Containing Mono- and Oligosaccharides. Chem. Rev. 2013, 113, 1851-1876.

(15) Pardo-Vargas, A.; Delbianco, M.; Seeberger, P. H. Automated Glycan Assembly as an Enabling Technology. Curr. Opin. Chem. Biol. 2018, 46, 48-55.

(16) Hoang, K. L. M.; Pardo-Vargas, A.; Zhu, Y.; Yu, Y.; Loria, M.; Delbianco, M.; Seeberger, P. H. Traceless Photolabile Linker Expedites the Chemical Synthesis of Complex Oligosaccharides by Automated Glycan Assembly. J. Am. Chem. Soc. 2019, 141, 90799086.

(17) Yu, Y.; Kononov, A.; Delbianco, M.; Seeberger, P. H. A Capping Step During Automated Glycan Assembly Enables Access to Complex Glycans in High Yield. Chem. - Eur. J. 2018, 24, 6075-6078.

(18) (a) Hahm, H. S.; Liang, C.-F.; Lai, C.-H.; Fair, R. J.; Schuhmacher, F.; Seeberger, P. H. Automated Glycan Assembly of Complex Oligosaccharides Related to Blood Group Determinants. J. Org. Chem. 2016, 81, 5866-5877. (b) Eller, S.; Collot, M.; Yin, J.; Hahm, H. S.; Seeberger, P. H. Automated Solid-Phase Synthesis of Chondroitin Sulfate Glycosaminoglycans. Angew. Chem., Int. Ed. 2013, $52,5858-5861$. 